\title{
The Impact of Remittance on Trade Balance: The Case of
}

\author{
Malaysia \\ Nguyen Phuc Hien ${ }^{1 *}$ \\ ${ }^{1}$ Banking and Finance Department, Foreign Trade University, Hanoi, Vietnam \\ *Nguyen Phuc Hien, E-mail: phuchienth@gmail.com
}

Received: September 28, 2017 Accepted: October 6, 2017 Online Published: October 18, 2017

doi:10.22158/jepf.v3n4p531

URL: http://dx.doi.org/10.22158/jepf.v3n4p531

\begin{abstract}
The paper aims to examines impact of remittance on Malaysia's trade balance in last over two decades. Using Ordinary Least Squares (OLS) regression model based on the annual data for twenty five years period from 1990 to 2015 to test the impact of remittance on the trade balance. The results showed the remittance influence on the trade balance positively. Our findings indicate that Malaysia did not face a symptom of Dutch disease impacted by the remittance. This is not surprised due to a small remittance to Malaysia, however, the interesting is that the remittance's fluctuation is semilar to trade balance's one.
\end{abstract}

\section{Keywords}

remittances, international competitiveness, balance of trade, Malaysia

\section{Introduction}

Remittances are an important financial inflow for many developing countries. In recent years the remitted amount to developing countries, including Malaysia, have increased sharply and in some cases exceeded inflows of official development assistance and other types of capital inflows.

Hence it is not surprising that remittances have become increasingly interesting to many researchers and economists. Most of their research focus on the positive impacts of remittance on growth, reducing poverty, balance of payment or education and health care.

In this paper, however, we are concerned with the macroeconomic impact of remittances on trade balance. Huge remittances can lead to the overshooting of a country's exchange rate and hurt its competitiveness, a phenomenon known as the Dutch disease. The overvaluated exchange rate makes the country's exports relatively expensive, imports cheaper, and thus puts pressure on the country's current account.

Remittances to Malaysia have reached \$ 1,56 billion in 2007 and 2014, from \$ 0,18 billion (1990). It is estimated that about one million Malaysian working and living abroad in 2010 which included those 
are highly educated and skillful (World Bank, 2011). The remittance inflow to Malaysia has increased tremendously in the last decade (World Bank, 2012). Remittance to Malaysia been the most important financial inflow after the FDI flow (Figure 1). It therefore is relevant to investigate whether remittances cause REER appreciation and impacts on trade balance in Malaysia in the last two decades. To do so this paper will apply an annual macroeconometric model to study the impact of the remittances and REER on trade balance.

The following section presents a literature review. The section 3 provides the trend of remittances inflow and balance of trade performance in Malaysia. The section 4 presents an empirical study of remittance and trade balance. Finally the conclusion and policy application are presented in the section 5.

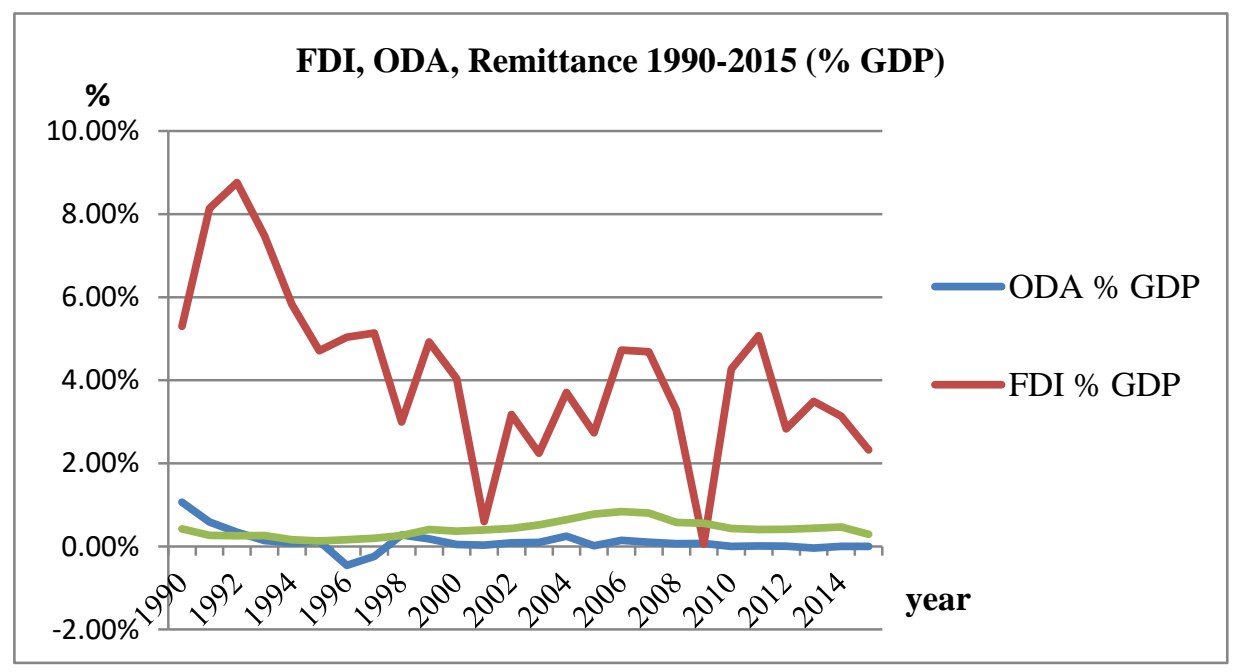

Figure 1. Malaysia's Remittances, FDI and ODA 1990-2015

\section{Literature Review}

Nowadays, remittances play an important role in developing economy of each country. Research papers [3]-[4]. One point which can be observed in most of the literature is remittances' positive influence over output of a country and sustainable economic growth, especially in case of developing countries. The degree of influence of remittances depends upon many factors which include policies of remittance recipient and remittance sender countries, capabilities and skills of the workers migrating, and geographic and geopolitical locations. According to a World Bank report, remittances can influence a number of macroeconomic factors including poverty, GDP and exchange rate. Remittances also enhance the debt servicing capacity of country. An inverse relationship exists between poverty and remittances (Adams \& Page, 2003). Empirical researchers have found the positive effect of remittances on poverty alleviation, education, and human skills of the remittances recipient families and 1.6 percent reduction in poverty is possible with $10 \%$ increase in remittances (Bourdet \& Falck, 2006). 
Lasagabaster, Maimbo and Sriyani (2005) have found a positive effect of remittances on growth. They explored that remittances can increase entrepreneurship in the country leading to economic growth.

Remittances are also considered a source to stabilize the exchange rates and a hide against oil price shocks. It is also perceived that remittances raise standard of living of households receiving remittances, and raise the amount of imported goods then make the balance of trade deficit. On the contrary, economists argue that even if the remittances have been spent on the consumption of goods and services, whether imported or domestic, these are still beneficial for the recipient country.

Bugamelli and Paterno (2011) explain that remittance can also increase the stock of foreign reserves and can be a way of surplus balance of payment account. They took the data of 60 developing countries from 1980 to 2003 and found a significant relationship of remittances with balance of payment.

Inflows of remittances not only influence economic growth of recipient countries but also are a source to reduce current account deficits. Remittances are also considered a source to reduce internal and external borrowing of a country. However, some scholars have highlighted their negative effects. They conclude that remittances may decrease output by reducing labor force participation. Warsi and Mubarik in Pakistan did a research about the effect of remittances on the balance of trade, GDP and economic growth indicators. The study shows that balance of trade can be effectively handled through regulating inflation, remittances and gross domestic product. The study concluded that an increase in remittances increases output of a country, decreases balance of trade and decreases inflation.

A huge remittance inflow compared to the size of the economy may also pose a significant hindrance to the expansion of the non-tradable sector. In addition, a significant portion of remittances receipt may actually be spent on domestic goods; in such cases, the Dutch disease phenomenon arises and policymakers will need to be mindful of this possibility. Moreover, significant remittances receipts may reduce the labour supply or labour market participation of recipients in which case remittances could lead adverse economic developmental outcomes. As a consequence, remittances flow via the over-valuation of local currencies of receiving economies may cause a deterioration of the external trade. Since remittances increase purchasing power in general within the receiving economy, they also promote domestic demand and preferences here may actually be in favour of imported goods and services. This fact often results in the deterioration of the external trade balance (Chami, Fullenkamp, \& Jahjah, 2003; Nguyen, 2017).

\section{Trend of Remittance and Trade Balance in Malaysia}

In Malaysia, the amount of remittances flows to this country increases significantly each year, from $\$$ 0,18 bill (1990) to $\$ 1,57$ bill (2015), remittances generally tend to increase, but there are some fluctuations in 2007-2015 period (Figure 1). This amount of remittance account for a small percentage compared to the trade balance. The Figure 1 shows an interesting is the trend of remittance is relatively semilar to Malaysia's trade balance.

As you can see from the chart, from 1990 to 1997, the amount of remittance is steady. The period 
1998-2007 there is a substantially increase in the amount of remittances in Malaysia, In 1998 the amount was estimated USD 0,19 bill. 10 years later, in 2007, it go up to USD 1.56 bill, almost 10 times higher. However, since 2008 the remittance has fluctuated and dropped to USD 1,1 bill in 2015. This fluctuations may be explained by the impact of the 2008 financial global crisis and changes in the use of foreign workers from other countries. Malaysia's migrants and workers send to their homeland less due to their lower income.

The Figure 2 illustrates the value of Malaysia's balance of trade between 1990 and 2015. Generally, the value of import and export fluctuated lightly, however, the trend was obviously upward. The balance of trade also witnessed a period of growing trend.

As you can see, during the period under study, the value of import and export rose and fell with a same direction, albeit with at different pace. within the first 8 years, it was zero as a result of the equivalence in the value of import and export. In line with the remittance, the surplus of trade balance increase from USD 0,9 bill to USD 39 bill (2007) and USD 51 bill (2008). Since 2008 the trade balance has a fluctuation and decline to the amount of trade surplus USD 23 bill in 2015. The change of Malaysia's trade balance is same with its remittance.

An interesting is that the remittance account for a small percent of Malaysia's current account and trade balance, however, the remittance flow has almost the same trend as the trade balance (Figure 2). Remittances flowing into Malaysia began to rise sharply in 1997-2007 period, reached about 1.56 billion US dollars. During this period, the balance of trade of Malaysia is strongly surplus, increase from about 16.2 billion dollars in 2001 to 38.45 billion dollars in 2007. In the next period (2007-2012), we can see a down and up trend in both the remittance and trade balance but different pace and time (Figure 2). Then the period of 2013-2015 both remittances and trade balance continues to tends to go down.

The underlying strength of the economy has meant that the effects of the current financial crisis in Asia (1997) have been somewhat less serious for Malaysia than for some other markets. Therefore, at that time, trade balance was still at surplus situation due to immediate policies of government. However, Malaysia does face macroeconomic and structural challenges if rapid economic growth is to be maintained. Beginning from 1997, trade balance of Malaysia has been gradually risen up to today. The economy at that time not only has a moderate upturn in large quantity but also in high quality own to extending and specializing in trade and agriculture that created a good future for Malaysian trade. 


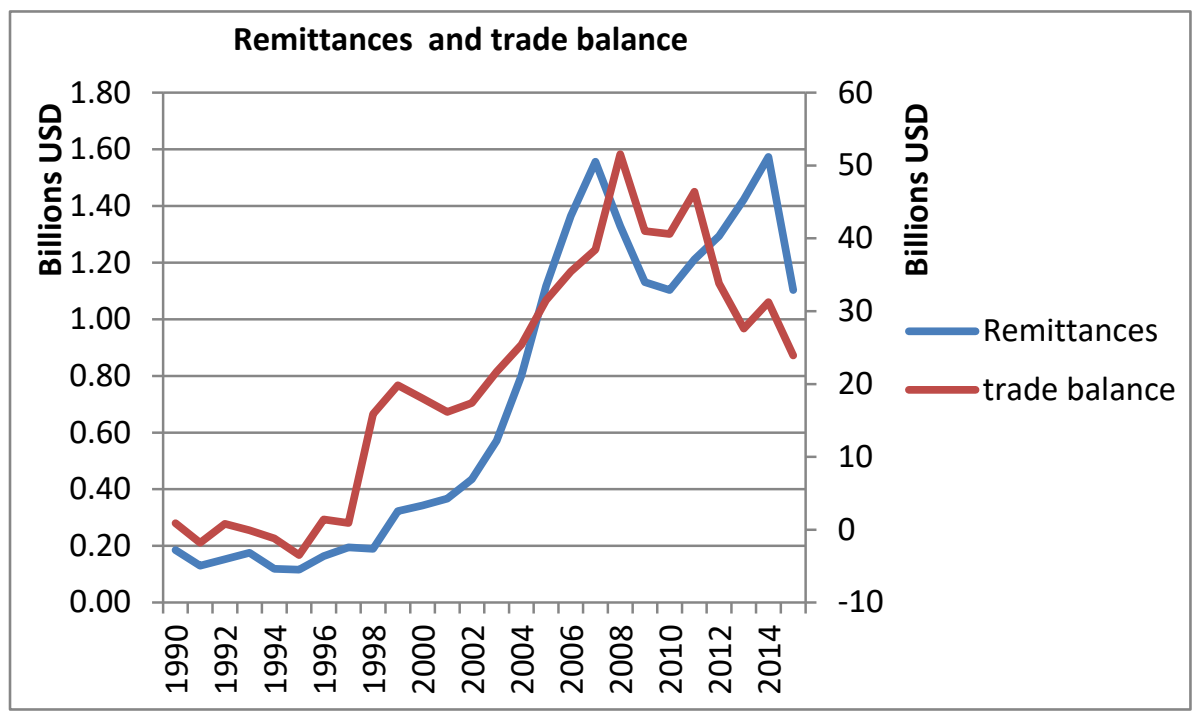

Figure 2. Malaysia's Remittances and Balance of Trade 1990-2015

Source: The World Bank.

\section{Empirical Study}

In order to test the impact of remittance flows on the trade balance of Malaysia duration 1990-2015, the model is selected and some variables are choiced with a time-series data will be done.

\subsection{Selected Model}

The empirical problem of our study is to find the impact of remittance flow on Malaysia's trade balance. Based on some previous researchs the impact of Remittances on External Trade Balance (Henry \& Wumi, 2012). In this study we are mainly concerned with whether or not remittances have affected the country's trade balance. For this we employ trade balance and examine its interaction with remittances and other factors driving in trade balance.

We take OLS regression model to test the impact of our selected annual variables on Malaysia's trade balance by using time series annual in Malaysia from 1990 to 2015. Following the literature on drivers of trade balance, our model can be written:

BOT $_{\mathrm{t}}=\beta_{0}+\beta_{1} * \mathrm{Rem}_{\mathrm{t}}+\beta_{2} *$ REER $_{\mathrm{t}}+\beta_{3} *$ Inflation $_{\mathrm{t}}+\beta_{4} * \mathrm{GDP}_{\text {Growth }}+\beta_{5} * \mathrm{ODA}_{\mathrm{t}}+\mathrm{u}_{\mathrm{t}}$

Where the BOT represents the country's import and export as a dependent variable. Rem (+/-) represents remittances inflow (share of GDP), REER (+/-) represents the country's competitiveness, ODA (+/-) represents official development assisstance. GDP Growth (+/-) represents national income. $\operatorname{Inf}(+/-)$ represents annual inflation. $\beta$ is the parameter to be estimated and $\mathrm{u}_{\mathrm{t}}$ stand for the errors.

\subsection{Choice of Variables and Data}

Balance of Trade (BOT): We use BOT (measured as exports of goods and services minus imports of goods and services) as our dependent variable.

Remittances are taken as a share of GDP. Remittances (Remit) is defined as Workers' remittances 
received comprise of current transfers by migrant workers. It is measured as a ratio of GDP. As discussed above, the remittances may cause the real exchange rate to appreciate. The remittances play a role in the determination of a country's exchange rate.

Inflation (CPI) is considered a determiant of change of trade balance. Inflation show sign of negative impact on the real exchange rate. Higher inflation lead to price of goods and services becoming more expensive in term of international market. In other words, the real effective exchange rate is appreciated and this discourage export and encourage import.

Real Effective Exchange Rate (REER) is the weighted average of a country's currency relative to an index or basket of other major currencies adjusted for the effects of inflation. The REER is defined as:

REER $=\sum$ country trade weight $($ country $\mathrm{j}) \times$ Real Exchange Rate (country $\mathrm{j}$ )

$\mathrm{N} \mathrm{j}=\mathrm{j}=1,2, \ldots \mathrm{N}$ are country's trading partners

Real Exchange Rate $=$ Nominal Exchange Rate $x \frac{\text { CPI foreign }}{\text { CPI Malaysia }}$

Inflation rate (Inflation) is the annual percentage change in Consumer Price Index (CPI).

Official Development Assisstance (ODA) are the indicators of the country's financial inflow. We do not include FDI and portfolio investment in our model due to lack of data during the research period. Following Lartey (2007) we expect Dutch disease effects for ODA inflows. The ODA inflow to a developing country is often directed at the improvement of institutional and human capital as well as various infrastructure projects.

Growth rate of Gross Domestic Product (GDP_growth) is the annual percentage change in the value of the GDP.

Data for all variables in this study were sourced from the World Bank, the International Monetary Fund (IMF), OANDA (Historical exchange rate). The study employs data on the variables and covering a period of twenty six years from 1990 to 2015. The data is on annual basis, the year 2010 was chosen as the base year for indicators: CPI, Exchange rate index, Inflation. Variables remittances, Inflation, ODA, imports, exports, were directly collected from the above sources, but REER (Real effective exchange rate) was calculated by the author.

\subsection{Result of Empirical Study}

Some specification tests are examined as a starting point to determine the reliability of coefficient estimates reported. There are no omitted variables, which strongly supports that the model complies with economic theories. Moreover, Heteroskedasticity test and Skewness/Kurtosis test for normality also proves that the model is good with constant variance and normal distribution. There is only one weakness which is the multicollinearity presented through high VIF values. However, the secondary regression's smaller R-squared value allows this study to ignore the multicollinearity because its influences on regression results are trivial.

Summary of the econometric model estimating the influences of Malaysia's remittances on its trade balance is presented in this table below:

Published by SCHOLINK INC. 
Table 1. The Results of Regression Model

\begin{tabular}{lllll}
\hline BOT & Coefficient & Std. Error & t-Statistic & $\mathrm{P}_{\text {value }}$ \\
\hline Remit & $2.06 \mathrm{e}+11$ & $5.09 \mathrm{e}+10$ & 4.04 & 0.001 \\
REER & $5.94 \mathrm{e}+08$ & $2.83 \mathrm{e}+08$ & 2.10 & 0.050 \\
Inflation & $2.92 \mathrm{e}+09$ & $1.70 \mathrm{e}+09$ & 1.72 & 0.102 \\
GDP_growth & $6.59 \mathrm{e}+07$ & $5.54 \mathrm{e}+08$ & 0.12 & 0.906 \\
ODA & -27.55323 & 11.64202 & -2.37 & 0.029 \\
Cons & $-9.95 \mathrm{e}+10$ & $3.18 \mathrm{e}+10$ & -3.13 & 0.006 \\
\hline
\end{tabular}

Dependent variable: BOT (balance of trade).

Number of observations: 26.

$\mathrm{F}(6,19): 11.58$

Prob > F: 0.000 .

R-squared: 0.7853

We take the OLS regression model with annual time series from 1990-2015. It is run by STATA program. The results is shown in Table 2. Our regression result were quite interesting. All the independent variables are statistically significant at 5 and 10 percent level except for the GDP Growth and Inflation variables. R squared is relatively high 0.7853 . It means the BOT can be explained by $78,53 \%$ all independent variables.

The findings given in Table1 show that Rem (remittances) and REER parameters have positive signs, while ODA parameters have negative signs. Remittances and REER are statistically significant at 5 percent level, while Inflation and GDP Growth is insignificant. Remittances show no signs of Dutch disease causing of appreciation of the real exchange rate and this did not undermines Malaysia's competitiveness in the long run. The effect of REER on the trade balance, however, appears to be positive.

Our findings on the impact of remittance on Malaysia's trade balance differed with other previous studies that remittance influences negatively on trade balance (Asif, Mohammad, \& Javed, 2013; Chami, Barajas, Fullenkamp, Gapen, \& Montiel, 2008).

Ratio of remittance against GDP (Remit) and ODA variables are both statistically significant at the 5 percent level, but have the opposite effects on Malaysia's trade balance. While Remit variable is positively signed, ODA shows the negative effect.

Real effective exchange rate (REER) variable is positively signed and is statistically significant at the 10 percent level. In more definitive terms, an 1 unit increase in REER produces about 0.594 US billion contemporaneous increase in Malaysia's balance of trade with ceteris paribus assumption. Given this finding, it can be remarked here that a rise of real exchange rate, will help to improve Malaysia's balance of trade. This can be explained by the fact that when REER rises, the Malaysia Ringgit will be 
depreciated, purchasing power of the Ringgit declines, which means that the domestic products become relatively cheaper than the foreign ones. As a result, a weaker Ringgit helps to push Malaysia's exports and improve its balance of trade.

The amount of Official Development Assistance (ODA) is also found to be highly statistically significant at the 5 percent level and negatively related to Malaysia's balance of trade. This agrees with theoretical expectation that when a country receives more ODA flows, leading to a higher foreign product demand. Otherwise, the export version of the explanation, also called resource movement effect (Corden \& Neary, 1982) states that as the aid could disproportionately be targeted at expanding non-tradable services such as health care, and education for which there is substantial unmet demand, it will increase wages in that subsector (given a fixed supply of skilled labor in the short run), will draw skilled labor into the non-tradable subsector, and will increase overall wages.

\section{Conclusion and Policy Implications}

Given the major findings in this study which clearly highlight the positive effect of the remittances on balance of trade in the long run, the negative of Official Development Assistance (ODA), but the positive of Real Effective Exchange Rate (REER). Therefore, there are three major policy issues arise from the empirical findings in this study:

First, a increase in the remittances inflow to Malaysia is observed to help improving balance of trade in the long run. Hence, the appropriate policy response is not to sterilize the remittance flows, but to learn to live with them. The appropriate policies are needed to ensure that these financial flows are properly channeled into economically productive uses so as to begin to contribute positively to the external sector of the economies. They should existonly to attract those migrants who have entrepreneurial qualities and intentions. The authorities should continue to give careful consideration to the implications of such remittances on the implementation of monetary and exchange rate policies. Like other forms of international capital flows, remittances are likely to be more effective in an enabling domestic economic and financial environment (Krishnan, 2009). In particular, an enabling investment climate may be more effective in encouraging remittances to flow into productive business investments than other forms of policy intervention. In addition, well-developed financial systems and sound institutions may encourage a higher share of remittances to be better invested in areas that may contribute to strengthening economic security at all levels in the longer-term. For instance, remittances received through a bank account are more likely to be saved and get invested in both physical and human capital; they may, moreover, also be channeled into microfinance ventures.

Second, the positive sign and significant nature of the REER variable in explaining the balance of trade also require some further comments. Increase in this variable indicates a depreciation of the local currency so the positive sign of REER is in line with theoretical expectation. This means that appropriate foreign exchange policies (policies in support of weaker national currencies in order to promote external trade) may be adopted in Malaysia to maintain a healthy trade balance for the country. 
However, these policies have to be carefully decided and consider their impacts on other sectors of economy.

Third, the increase in ODA flowing to Malaysia has its negative impact on balance of trade. To effectively mobilization and usage of ODA, it is necessary to: (i) raise awareness and correct understanding of the nature of ODA; (ii) use ODA selectively in consistent and harmonious combination with other investments; (iii) speed up ODA disbursement; (iv) maximize efficiency and spillover effects of ODA; (v) expand ODA beneficiary to the private sector to implement programs and projects serving the public interest; (vi) reasonably plan to decentralize management and use of ODA; and (vii) strengthen monitoring and management of ODA, etc. Like the policies for remittances, more than attracting, Government should have policies to use effectively these foreign capital flows, encourage investing in trade sectors to raise international competiveness of Malaysia.

\section{References}

Acosta, P. A., Lartey, K. K., \& Mandelman, F. S. (2009). Remittances and Dutch Disease. Journal of International Economics, 79, 102-116. https://doi.org/10.1016/j.jinteco.2009.06.007

Adams, R., \& Page, J. (2003). International Migration, Remittances, and Poverty in Developing Countries. World Bank Policy Research Working Paper 3179. Washington D. C. World Bank.

Asif, Z. W., Mohammad, S. M., \& Javed, H. (2013). Effect of Workers' Remittances on Balance of Trade, Inflation and Economic Growth in Pakistan. Pakistan business review.

Bourdet, Y., \& Falck, H. (2006). Emigrants' Remittances and Dutch Disease in Cape Verde. International Economic Journal (forthcoming). https://doi.org/10.1080/10168730600879323

Bugamelli, \& Paterno. (2011). Output Growth Volatility and Remittance. Economica, 78(311), 480-500. https://doi.org/10.1111/j.1468-0335.2009.00838.x

Chami, R. A., Barajas, T. C., Fullenkamp, C., Gapen, M., \& Montiel, P. (2008). Macroeconomic Consequences of Remittances. Washington DC, International Monetary Fund.

Chami, R. A., Fullenkamp, C., \& Jahjah, S. (2003). Are Immigrant Remittances Flows a Source of Capital for Development? Washington D. C., International Monetary Fund.

Chee-Keong, Choong, \& Ying-Yin, Koay. (2013). The Nexus Between Worker Remittances and Economic Growth in Malaysia. Prosiding Persidangan Kebangsaan Ekonomi Malaysia Ke VIII 2013.

Corden, \& Neary (1982). Booming Sector and De-Industrialisation in a Small Open Economy. Paper, IIASA, Laxenburg Austria.

Glytsos, N. P. (2005). The contribution of remittances to growth: A dynamic approach and empirical $\begin{array}{lllll}\text { analysis. Journal of } & \text { Economic Studies, }\end{array}$ https://doi.org/10.1108/01443580510631379

Henry, O., \& Wumi, K. O. (2012). Migrant Workers' Remittances and External Trade Balance in Sub-Sahara African Countries. International Journal of Economics and Finance, 5(3), 2013. 
Retrieved February 22, 2013, from http://www.ccsenet.org/journal/index.php/ijef/article/ view/25046

Krishnan, S. (2009). The Impact of Remittances on Economic Insecurity. UN.

Lartey, E. K. K. (2007). Capital inflows and real exchange rate: An empirical study of Sub-Saharan Africa. Journal of International Trade and Economic Development, 16(3), 337-357. https://doi.org/10.1080/09638190701526667

Lartey, E. K. K., Mandelman, F. S., \& Acosta, P. A. (2010). Remittances, Exchange Rate Regimes and the Dutch Disease: A Panel Data Analysis. Washington, D.C. World Bank.

Lasagabaster, E., Maimbo, S. M., \& Sriyani, H. (2005). Sri Lanka's Migrant Labour Remittances: Enhancing the Quality and Outreach of the Rural Remittance Infrastructure. World Bank.

Lopez, H., Molina, L., \& Bussolo, M. (2007). Remittances and the real exchange rate. Washington, D.C. World Bank.

Nguyen, P. H. (2017). Remittance and Competitiveness: A Case Study of Vietnam, 5(2), 79-83.

World Bank. (2011). Malaysia economic monitor-brain drain. Washington D.C.: The world bank.

World Bank. (2012). World Development Indicators. Retrieved October 23, 2012, from http://www.data.worldbank.org/data-catalog/world-development-indicators 